\title{
New Occurrences of Fossil Homolidae from the Eastern Pacific
}

\author{
Torrey Nyborg, Alessandro Garassino
}

\section{Torrey Nyborg}

tnyborg06g@llu.edu

Department of Earth and Biological Sciences, Loma Linda University, Loma Linda, CA 92354, U.S.A.

\section{Alessandro Garassino}

Natural History Museum, Palaeontology Department, Corso Venezia 55, 20121 Milano, Italy.
BOL. SOC. GEOL. MEX. 2017

VOL. 69 NO. 1

P. $135-148$

\section{ABSTRACT}

New specimens of fossil homolid crabs collected from Cretaceous and Paleogene rocks from Canada and the western United States increase the fossil record of the Homolidae De Haan, 1839. Cretalamoha n. gen., n. sp. is reported from the Campanian Pender Formation, Vancouver Island, British Columbia, Canada. A new species, Paromola roseburgensis n. sp. from the early Eocene Roseburg Formation in Oregon, U.S.A. represents the second report for the genus in the fossil record and the first one in North America, extending the spatial and temporal ranges of the genus, from the Oligocene of Argentina to the Eocene of the North Eastern Pacific. Additional material from the Oligocene of Judkins Ridge, near Eugene, Oregon, U.S.A. assigned to Palehomola gorrelli Rathbun, 1926, allows re-evaluation of the systematic position of the genus, previously ascribed to the Homolodromiidae Alcock, 1900. The definite presence of linea homolica justifies removal of Palehomola from this family and inclusion within the Homolidae.

Keywords: Brachyura, Homolidae, Cretaceous, Eocene, U.S.A., Vancouver Island, Canada.

\section{RESUMEN}

Nuevas muestras de cangrejos fósiles homólidos recogidos de rocas del Cretácico y Paleógeno de Canadá y el oeste de Estados Unidos aumentan el registro fósil de la Homolidae De Haan, 1839. Cretalamoha n. gen., n. sp. se reporta en la Formación Campania Pender, en la isla de Vancouver, Columbia Británica, Canadá. Una nueva especie, Paromola roseburgensis n. sp. de la Formación Roseburg de Oregon, Estados Unidos, del Eoceno Temprano representa el segundo informe para el género en el registro fósil y el primero en América del Norte, extendiendo el rango espacial y temporal del género, desde el Oligoceno en Argentina hasta el Eoceno en el Pacífico Nororiental. El material adicional del Oligoceno de Judkins Ridge, cerca de Eugene, Oregon, Estados Unidos asignado a Palehomola gorrelli Rathbun, 1926, permite la re-evaluación de la posición sistemática del género, previamente atribuido a la Homolodromïdae Alcock, 1900. La presencia definida de linea homolica justifica la eliminación de $\underline{\mathrm{Pa}}$ lehomola de esta familia, y su inclusión dentro de la Homolidae.

Palabras clave: Brachyura, Homolidae, Cretáceo, Eoceno, Estados Unidos, Vancouver, Canadá. 


\section{Introduction}

Homolid crabs from the West Coast of North America are relatively rare, and their systematic position is usually based upon individual specimens. The discovery of two new fossil homolid crabs from this area is significant, as it nearly doubles the currently known fossil record of the family Homolidae from the West Coast of North America. To date, only Latheticocarcinus ludvigseni Schweitzer, Nyborg, Feldmann and Ross, 2004 has been reported from the Cretaceous of Vancouver Island, British Columbia, Canada. With the description of Cretalamoha boweni, the number of known homolid fossil crabs from Vancouver Island has doubled. Similarly, only Paromolopsis piersoni Schweitzer, Nyborg, Feldmann and Ross, 2004 has previously been reported in Oregon, U.S.A. With the description of Paromola roseburgensis n. sp. herein, and the placement of Palehomola gorrelli Rathbun, 1926 back into the family Homolidae, the entire number of known fossil homolid crabs from Oregon has tripled. The other fossil homolid crab from this area previously reported was Homola vancouverensis Schweitzer, 2001 from the Eocene of Washington State, U.S.A.

\section{Geological settings}

\subsection{GANADA}

Cretalamoha boweni n. gen., n. sp. is preserved in a calcareous concretion collected from a river cut bank along the Puntledge River near the town of Courtenay, Vancouver Island, British Columbia, Canada. The Pender Formation is part of the Upper Gretaceous Nanaimo Group of southwestern British Columbia and is composed of up to 300 meters of mudstone and siltstone interbedded with sandstone (Haggart, 1991; Mustard, 1994). The Nanaimo Group is subdivided into twelve formations, namely, Sidney Island, Comox, Haslam, Extension, Pender, Protection, Cedar District, De Courcy, Northumberland, Geoffrey, Spray, and
Gabriola (Haggart, 1991; Mustard, 1994). These formations consist of mudstones, fine sandstones, and sandstone-conglomerates deposited primarily in an outer neritic to bathyal marine setting as submarine fan deposits, but with some nearshore deposits included within the Nanaimo Group (Mustard, 1994). The Nanaimo Group outcrops along the northeastern coastline of Vancouver Island extending from Campbell River in the north to Saanich Peninsula in the south (Mustard, 1994). It is also exposed to the adjacent Gulf Islands and northern San Juan Islands in Washington, U.S.A. (refer to Mustard, 1994 for a detailed stratigraphy of the Nanaimo Group). The age of the Nanaimo Group ranges from Turonian to Maastrichtian, with the Pender Formation considered early Campanian (Haggart, 1991; Mustard, 1994). Decapod crustaceans collected from this unit include: Hoploparia horrida Schweitzer, Feldmann, Fam, Hessin, Hetrick, Nyborg and Ross, 2003; Hoploparia tshudyi Schweitzer and Feldmann, 2001; Limuparis canadensis (Whiteaves, 1895); Limuparis vancouverensis (Whiteaves, 1895); and Eucorystes platys Schweitzer, Feldmann, Fam, Hessin, Hetrick, Nyborg and Ross, 2003.

\subsection{OREGON}

Paromola roseburgensis n. sp. is preserved in a calcareous concretion collected from a road cut exposure near the town of Dora, Oregon $\left(43^{\circ}\right.$ $\left.10.448^{\prime} \mathrm{N}, 123^{\circ} 59.260^{\prime} \mathrm{W}\right)$. The area has been mapped as part of the Roseburg Formation (Walker and MacLeod, 1991). The Roseburg Formation was named by Baldwin (1974) for basalts, overlying interbedded sandstones, and siltstones exposed in the Roseburg, Oregon area. The formation consists of about 3000 meters of thin rhythmically-bedded turbidite sandstones and shales with smaller amounts of conglomerates and sandstones (Baldwin et al., 1973; Baldwin, 1974; Prothero, 2009). The Roseburg Formation is one of three formations, Roseburg, Lookingglass, and Flournoy formations constituting the Umpqua Group (Baldwin, 1974). The Umpqua Group consists of several thousand meters of lower-middle Eocene 
strata that were exposed in southwestern Oregon (Baldwin et al., 1973; Baldwin, 1974; Prothero, 2009). Recent magnetostratigraphic studies, combined with the biostratigraphy of planktonic and benthic microfossils by Prothero (2009), constrained the age estimates of the formations within the Umpqua Group to 52.3 - $47 \mathrm{Ma}$, with the lower Eocene Roseburg Formation assigned an age of 50.8 - 52.3 Ma (Prothero, 2009). This is the first report of a fossil crab from this formation. Specimens of Palehomola gorrelli Rathbun, 1926, examined in this work come from a railroad cut exposure named Judkins Ridge near Eugene, Oregon. This locality is mapped as part of the Eugene Formation (McClaughry et al., 2010). The Eugene Formation consists of shallow-water marine deposits with interbedded continental rocks (Allison and Felts, 1956; McKeel, 1984; Retallack et al., 2004; McClaughry et al., 2010). The Eugene Formation has been assigned a late Eocene to early Oligocene age based upon its stratigraphic position above a 40.1 Ma tuff at Eugene, and below a 31.4 Ma basalt north of Eugene. Bivalves, gastropods, crabs, trace fossils, and plant faunas have been previously reported from this Formation (Rathbun, 1926; Steere, 1958; Hickman, 1969; Retallack et al., 2004). Decapod crustacean specimens reported from the Eugene Formation include: Raninoides eugenensis Rathbun, 1926 and Palehomola gorrelli Rathbun, 1926. Callianassa and Meggokos have also been figured in papers from the Eugene Formation (Steere, 1958; Retallack et al., 2004).

Abbreviations. CDM, Courtenay and District Museum Palaeontology Centre, Vancouver Island, British Columbia, Canada; UWBM, The Burke Museum of Natural History and Culture, University of Washington, Seattle, Washington State, U.S.A.; USNM: United States National Museum of Natural History, Smithsonian Institution, Washington, D.C.; lcxp: length of carapace; wcxp: width of carapace (including lateral spines); P1, P5: pereiopods 1 and 5.

\section{Systematic Paleontology}

\author{
Infraorder Brachyura Linnaeus, 1758 \\ Section Homoloida Karasawa, Schweitzer and \\ Feldmann, 2011 \\ Superfamily Homoloidea De Haan, 1839 \\ Family Homolidae De Haan, 1839
}

\section{Genus Cretalamoha new genus}

Diagnosis. Carapace as long as wide; well defined dorsal carapace regions, marked by deep incised grooves; short and rounded rostrum; subhepatic region with three subhepatic spines; smooth anterolateral and posterolateral margins; tuberculate dorsal carapace, marked by strong calcified spines in epi- and protogastric regions.

Etymology. After the Cretaceous, the geological age of the studied specimen, and Lamoha Ng, 1998, which shares some morphological characters with the new genus. Gender is feminine.

Type of species. Cretalamoha boweni n. sp., by monotype.

Description. As for the type species Cretalamoha boweni.

Discussion. Recognition of Cretalomoha as a new genus is based upon the short rostrum, with rounded tip, the antero- and posterolateral margins smooth, and the strong calcified spines on the epi- and protogastric regions. This combination of characters distinguishes the new genus from all fossil genera known to date (Bell, 1863; Beurlen, 1928; Bishop, 1983, 1988; Karasawa, 1992; Guinot and Richer de Forges, 1995; Collins, 1997; Collins et al., 2005; Collins and Saward, 2006; Feldmann and Schweitzer, 2009; De Angeli and Alberti, 2012; Garassino et al., 2015).

\section{Cretalamoha boweni new species}

(Figures 1 and 2)

Description. Dorsal carapace longitudinally square in outline, as long as wide; well defined carapace regions; tuberculate dorsal surface, 


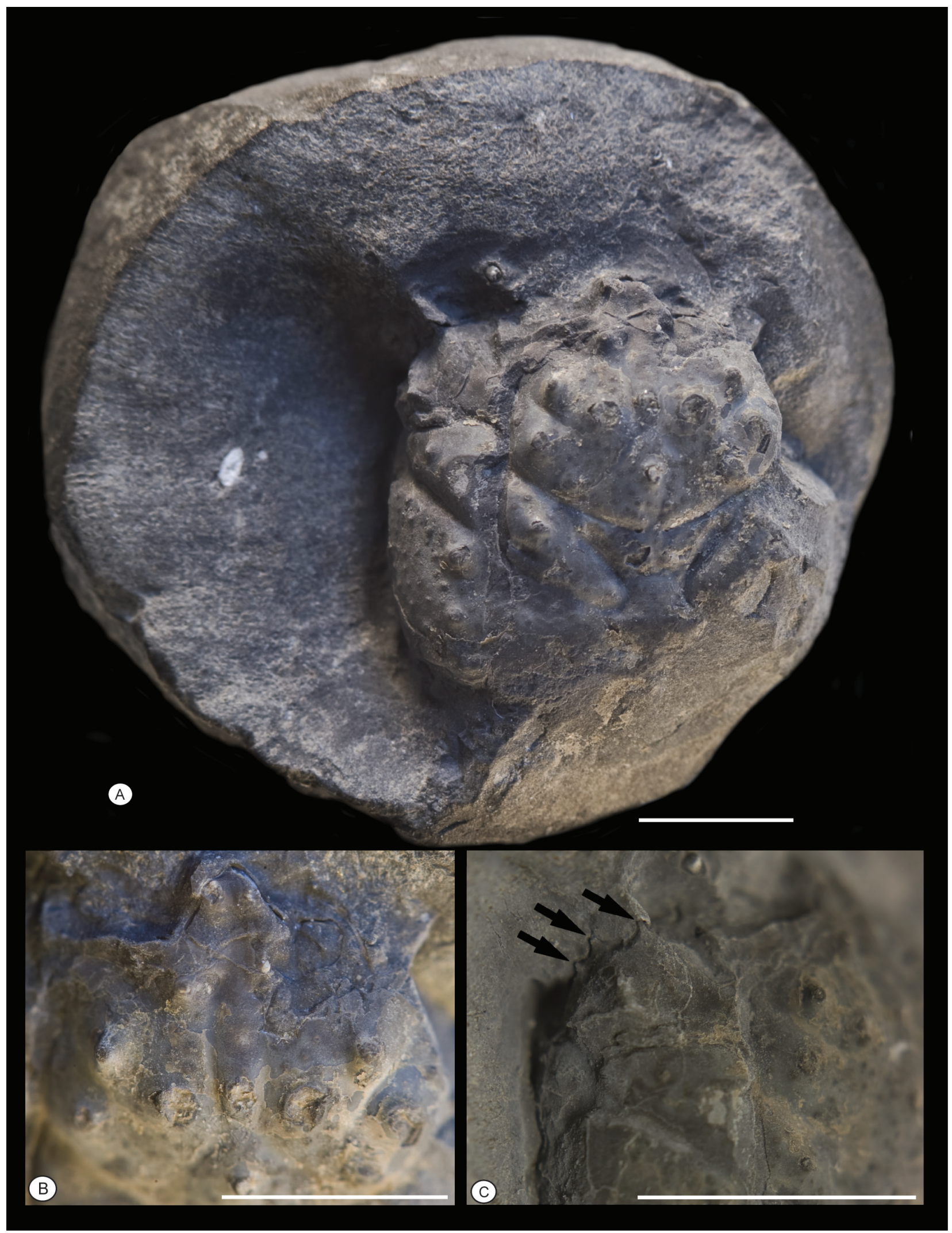

Figure 1 Cretalamoha boweni n. gen., n. sp., CDM 047. A) dorsal view of the carapace. B) close-up view of rostrum. C) close-up view of subhepatic region, three subhepatic spines noted by black arrows. Scale bar equals $1 \mathrm{~cm}$. 


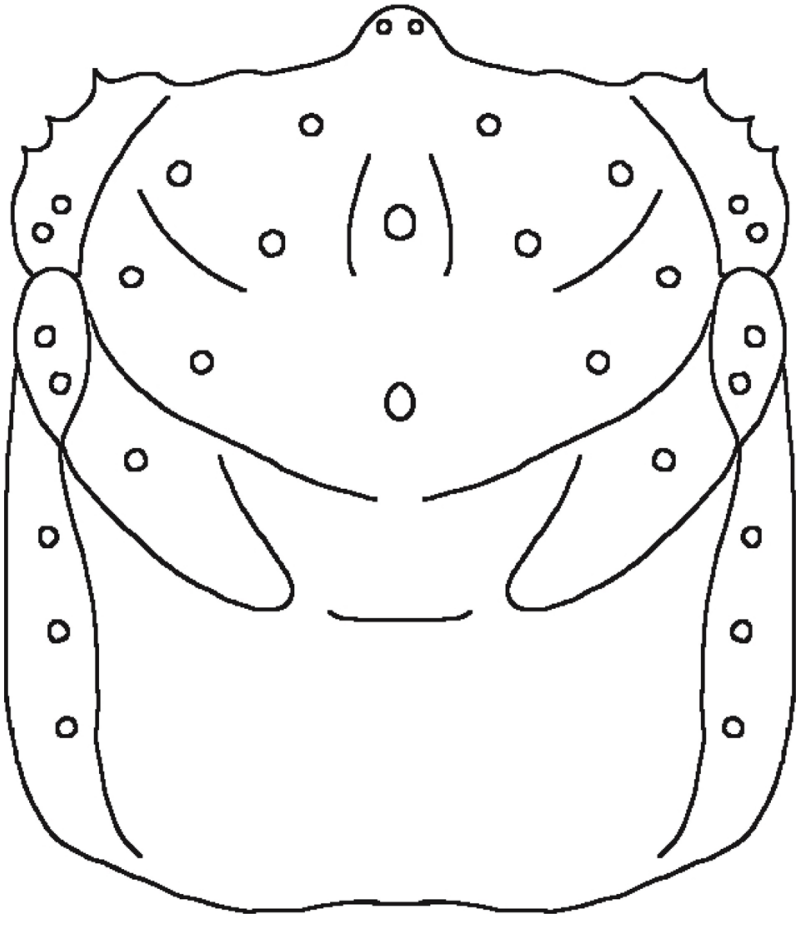

Figure 2 Cretalamoha boweni n. gen., n. sp., line drawing.

marked by strong calcified spines; rimmed anterior and posterior margins; well-developed linea homolica, sinuous in outline; straight lateral margins of dorsal carapace, weakly vaulted longitudinally and weakly vaulted transversely between linea homolica; simple rostrum, wider at the base, with rounded tip; one small lateral spinule, located close to the tip; angular subhepatic region with three subhepatic spines; straight and smooth antero- and posterolateral margins; straight posterior margin, weakly concave medially; each epigastric and protogastric region consisting of a large node, divided by a deep groove; epigastric region with three strong calcified spines; protogastric region with two strong calcified spines; poorly defined epi- and protogastric regions; well-defined meso- and metagastric regions, with one central prominent calcified spine; weakly depressed and poorly defined urogastric regions; poorly defined cardiac and intestinal regions; well defined and inflated epibranchial region, with two strong calcified spines; meso- and metabranchial regions posi- tioned on either side of urogastric region, weakly inflated, with at least three strong calcified spines; deeply incised cervical groove, originating axially, curving anteriorly in concave arc toward linea homolica, deflecting around epibranchial region and extending across linea homolica in weakly concave arc around hepatic regions on flank; deeply incised branchiocardiac groove.

Etymology. The species name is named after the collector of this sole specimen Dan Bowen of Courtenay, Vancouver Island, British Columbia, Canada.

Material. One specimen in dorsal view with just preserved carapace, holotype CDM 047.

Locality Type. Access at end of Cessford Road near the town of Courtenay, $500 \mathrm{~m}$ down hydro right of way, accessed by a trail at cable car crossing on a river cut bank north side of the Puntledge River, Vancouver Island, British Columbia, Canada.

Geological age. Early Campanian Pender Formation.

Measurements. CDM 047- lcxp: 14 mm; wcxp: $14.3 \mathrm{~mm}$.

Discussion. Guinot and Richer de Forges (1995) reported three families within Homoloidea De Haan, 1839 as follows: Homolidae De Haan, 1839; Poupiniidae Guinot, 1991; and Latreillidae Stimpson, 1858. According to Guinot and Richer de Forges (1995) the linea homolica distinguishes Homolidae from Poupiniidae and Latreillidae. Based upon this main diagnostic characteristic, Cretalamoha $\mathrm{n}$. gen. is assigned to Homolidae based on the presence of a well-marked linea homolica not present in the other two families within Homoloidea. Among the extant genera, revised by Guinot and Richer de Forges (1995), Cretalamoha n. gen. shares some characteristics with Lamoha Ng, 1998 (= Hypsophrys Wood-Mason in Wood-Mason and Alcock, 1891), such as a square outline of the carapace, the areolated carapace dorsal regions, the strong calcified spines on the gastric regions (like $L$. murotoensis Sakai, 1979), and the smooth posterolateral margins (like L. longipes Alcock and Anderson, 1899; 
L. superciliosa Wood-Mason in Wood-Mason and Alcock, 1891; L. murotoensis (Sakai, 1979). However, the new genus differs in having a short and rounded rostrum (usually bifid in all extant species of Lamoha), the lack of pseudorostral spines, and the smooth anterolateral margins.

\section{Genus Paromola Wood-Mason in Wood-Mason and Alcock, 1891}

Type species. Dorippe cuvieri Risso, 1815, by original designation.

Species. Paromola bathyalis Guinot and Richer de Forges, 1995 (extant); P. roseburgensis n. sp. (fossil, this study); P. cuvieri (Risso, 1815) (extant); P. crosnieri Guinot and Richer de Forger, 1995 (extant); P. japonica Parisi, 1915 (extant); P. macrochira Sakai, 1961 (extant); P. rathbunae Porter, 1908 (extant); P. vetula Crawford, 2008 (fossil).

\section{Paromola roseburgensis new species}

(Figures 3 and 4)

Diagnosis. Well defined dorsal carapace regions, marked by shallow incised grooves; long, pointed, and moderately upturned rostrum; dorsal carapace widest at level of the mesobranchial region, narrowing in anterior third; pseudorostral spines, slightly longer than rostrum and ornamented with one small median external spinule; anterolateral margin with one laterally-projecting spine; posterolateral margin strongly convex, rimmed by three laterally-projecting spines; posterior margin consisting of three arcs, one axially convex and two laterally concave; strongly spinose dorsal carapace.

Description. Dorsal carapace longitudinally ovate in outline, longer than wide, widest at metabranchial region, narrowing in anterior third; well defined carapace regions; spinose dorsal surface, marked by variously-sized acute spines; rimmed anterior and posterior margins; well-developed linea homolica, sinuous in outline; convex lateral margins of dorsal carapace, weakly vaulted longi- tudinally and weakly vaulted transversely between linea homolica; simple rostrum, pointed, well developed, axially sulcate, and moderately upturned; pseudorostral spines present on anterior margin, directed anteriorly and upward, slightly longer than rostrum, and ornamented with one small median external spinule; angular subhepatic region; point of inflection marked by anterolaterally and upward-projecting subhepatic spines, the first one slightly longer than the second one; anterolateral margin with one well-developed laterally-projecting spine; strongly convex posterolateral margin, rimmed by three laterally-projecting spines, the first and the third ones longer than the second one; posterior margin consisting of tri-partite segments, almost equal in length: one central convex segment proximal to intestinal region and two lateral concave segments; each epigastric region consisting of a large anterior node, with two protogastric spines (broken); epi- proto- and mesogastric regions poorly defined; metagastric region well defined, with one central prominent swelling; urogastric regions weakly depressed and poorly defined; pentagonal cardiac region, narrowing anteriorly, spinose, with three swellings, one anterior swelling separated by a shallow depression from two posterior swellings; poorly defined intestinal region; mesobranchial regions positioned on either side of urogastric region, weakly inflated, with at least one small spine (broken); weakly inflated metabranchial regions, with at least four small spines (broken); slightly incised cervical groove, originating axially, curving anteriorly in concave arc towards linea homolica, deflecting around epibranchial region, and extending across linea homolica in a weakly concave arc around hepatic regions on flank; poorly defined branchiocardiac groove; partially preserved $\mathrm{P} 1$ and P5; P5 long merus, with small spines in evenly spaced linear arrangement along the whole length.

Etymology. The species name alludes to the Roseburg Formation where the studied specimen was collected. 


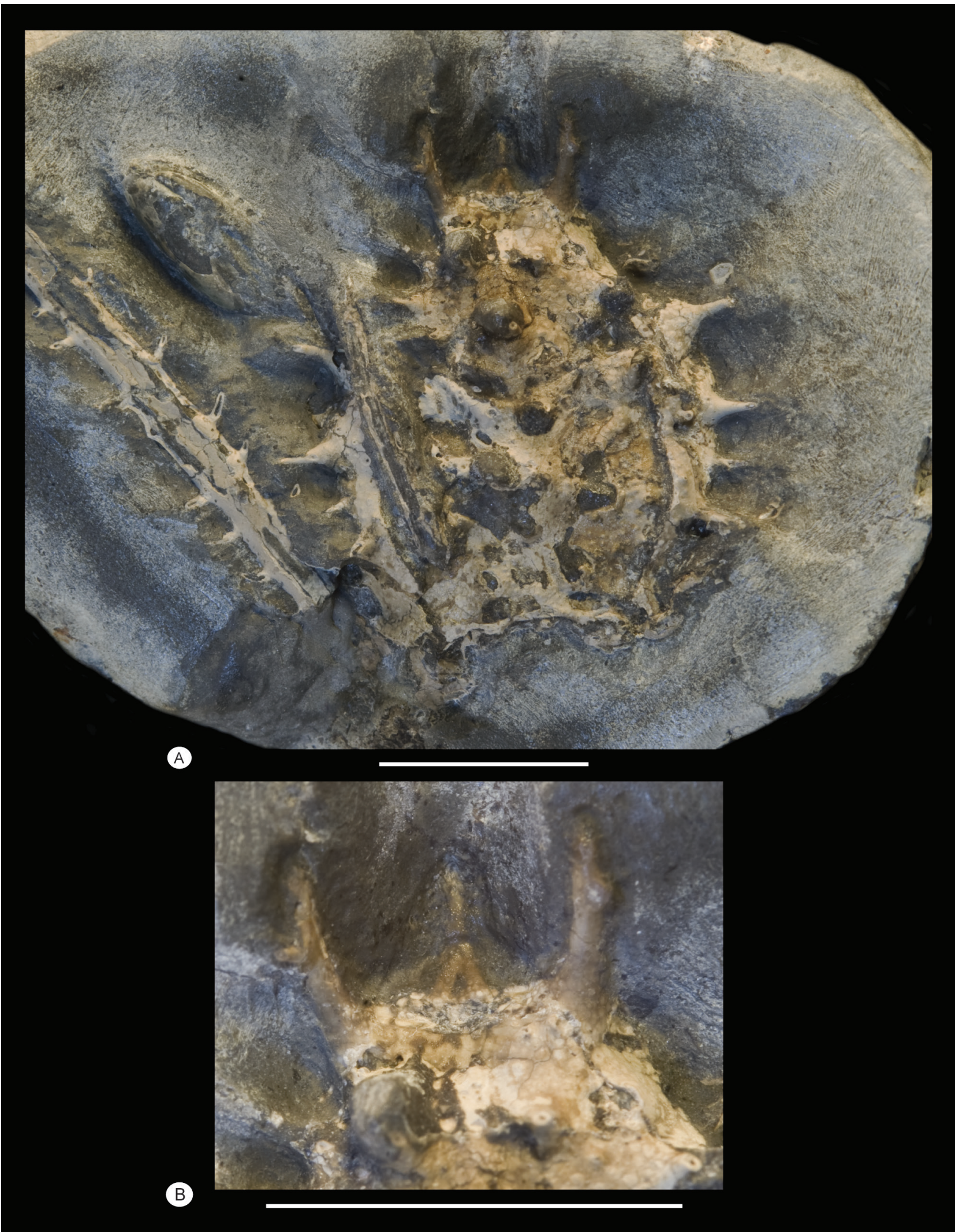

Figure 3 Paromola roseburgensis n. sp., UWBM 104435. A) dorsal view of the carapace. B) close-up view of rostrum. Scale bar equals 1 cm. 


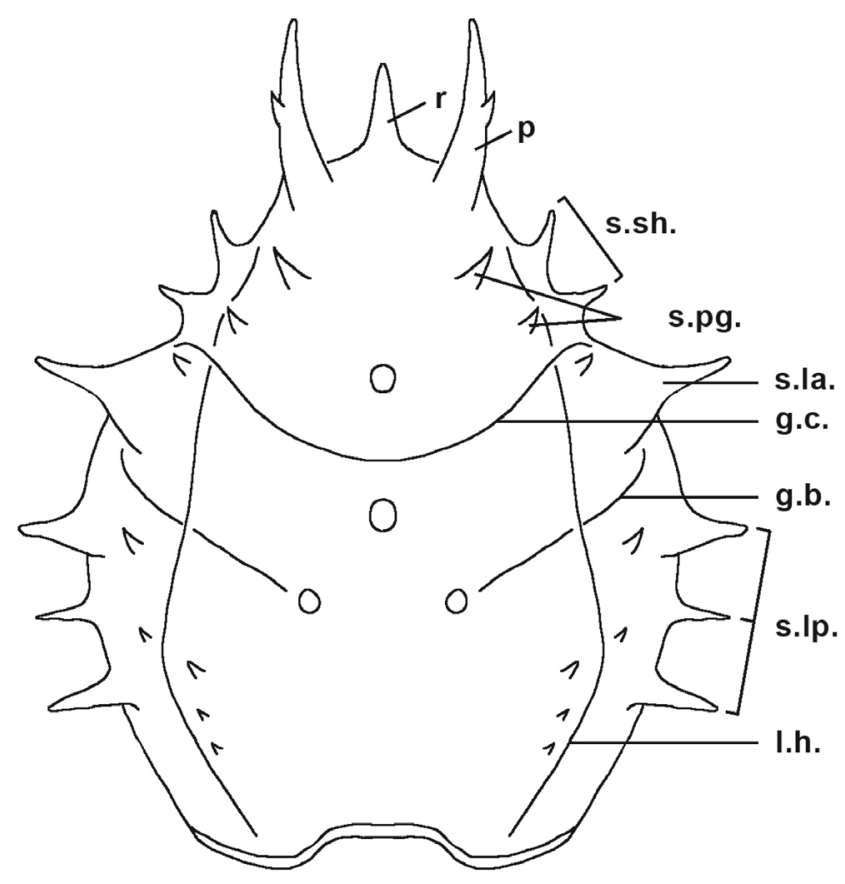

Figure 4 Paromola roseburgensis n. sp., line drawing (r: rostrum; p: pseudorostral spine; s.sh: subhepatic spines; s.pg.: protogastric spines; s.la.: anterolateral spine; g.c.: cervical groove; g.b.: branchiocardiac groove; s.lp.: posterolateral spines; I.h.: linea homolica).

Material. One specimen in dorsal view with $\mathrm{P} 1$ and P5 is partially preserved, holotype UWBM 104435.

Locality Type. The sole specimen was collected from a roadcut that exposes turbidite sandstones and shales typical of the Roseburg Formation, (Baldwin, 1974; Prothero, 2009). This locality is mapped as part of the Roseburg Formation, Coos County, Oregon (Baldwin et al., 1973; Baldwin, 1974; Walker and MacLeod, 1991).

Geological age. Early Eocene.

Measurements. UWBM 104435 - lcxp: 24.2 mm; wcxp: $23 \mathrm{~mm}$.

Discussion. Guinot and Richer de Forges (1995) revised the superfamily Homoloidea, including three families: Homolidae De Haan, 1839, Poupiniidae Guinot, 1991, and Latreillidae Stimpson, 1858. Following Guinot and Richer de Forges (1995), the studied specimen has been assigned to the Homolidae due to the presence of well-defined linea homolica. Among the extant genera of this family, Paromola Wood-Mason in Wood-Mason and Alcock, 1891, and Dagnadus Guinot and Richer de Forges, 1995, exhibit an external dorsal carapace morphology similar to that of the studied specimen herein. The finely-spinose ornamentation, the posterior margin with one axial concave arc and two distal concave arcs, and the pseudorostral spines, nearly as long as the rostrum and bearing only a small external spinule, allow us to assign the studied specimen to Paromola.

Paromola includes seven extant species and just one fossil species, P. vetula Crawford, 2008, from the Paleogene of Río Negro Province (Argentina) (Guinot and Richer de Forges, 1995; Crawford, 2008). We justify the description of $P$. roseburgensis n. sp. based on the posterolateral margin with three laterally-projecting spines (five laterally-projecting spines in $P$. vetula); a cardiac region with three swellings, one anterior and two posterior (two anterior and one posterior in $P$. vetula); and posterior margin consisting of tri-partite segments, one central longer and two lateral shorter (posterior margin consisting of tri-partite segments, equal in size in P. vetula).

Among the extant species, P. roseburgensis n. sp. shares only with P. japonica Parisi, 1915, some external dorsal carapace characters, such as: the dorsal carapace strongly spinose; the anterolateral margin with one well-developed laterally-projecting spine; and two protogastric spines. However, the posterolateral margin with three laterally-projecting spines and the posterior margin consisting of tri-partite segments distinguish $P$. roseburgensis $n$. sp. from the extant species.

The report of $P$. roseburgensis n. sp. from North America enlarges the paleogeographic distribution for the genus, which was previously only recognized in southern South America.

\section{Genus Palehomola Rathbun, 1926}

Type species. Palehomola gorrelli Rathbun, 1926, by monotypy.

Species. Palehomola gorrelli Rathbun, 1926. 
Palehomola gorrelli Rathbun, 1926

(Figures 5 and 6)

Palehomola gorrelli Rathbun, 1926: 86, 87, Pl. 21

(Figures 1 and 2).

Palehomola gorrelli- Glaessner, 1969: R490 - Collins, 1997: 54, 64, 65 - Nyborg, 2002: 46-49 -

Schweitzer, 2001: 522 - Schweitzer et al., 2004: 133, 142-145, (Figures 6 and 7) - Feldmann et al., 2008: 503.

Diagnosis. By Schweitzer et al. (2004). Carapace slightly longer than wide, W/L about 0.90 , ovate; bulbous and convex branchial regions; steep and rounded lateral sides; downturned central rostral spine, triangular sulcate; stout lateral rostral spines, directed forward; large and inflated subhepatic region, with large triangular spine; inflated subepibranchial region, with large tubercle; moderately well-developed cervical groove; weakly developed branchiocardiac groove; long, slender, granular appendages; male abdominal somites with pleurae.

Emended diagnosis (present work). Longer than wide and ovate carapace; bulbous and convex branchial regions; steep antero- and posterolateral margins, slightly rounded, and smooth; long rostrum, pointed strongly downturned; pseudorostral spines slightly longer than rostrum and ornamented with two small basal spinules; large, inflated subhepatic region, with one large triangular spine; well-developed cervical and branchiocardiac grooves; well-developed linea homolica, sinuous in outline; long, slender, granular appendages; male pleonal somites with pleurae.

Description (based on holotype and additional specimens). Dorsal carapace longitudinally ovate in outline, longer than wide, widest at metabranchial region, narrowing in anterior third; well defined carapace regions; smooth dorsal surface; rimmed anterior and posterior margins; welldeveloped linea homolica, sinuous in outline; convex lateral margins of dorsal carapace, weakly vaulted longitudinally and weakly vaulted transversely between linea homolica; simple rostrum, pointed, well developed, axially sulcate, and strongly downturned; pseudorostral spines present on anterior margin, directed anteriorly and upward; pseudorostral spines slightly longer than rostrum and ornamented with two small basal spinules; angular, wide, and inflated subhepatic region, with one large triangular spine; antero- and smooth posterolateral margins; straight and rimmed posterior margin; each epigastric region consisting of a large anterior node, with two strong calcified spines; poorly defined epi- proto- and mesogastric regions; metagastric region well defined, with one central prominent calcified spine; weakly depressed and poorly defined urogastric regions; pentagonal cardiac region, narrowing anteriorly, smooth, with a pair of median pits; poorly defined intestinal region; mesobranchial regions positioned on either side of weakly inflated urogastric region; weakly inflated metabranchial regions, with at least three small spines; deeply incised cervical groove, originating axially, curving anteriorly in concave arc toward linea homolica, deflecting around epibranchial region and extending across linea homolica in a weakly concave arc around hepatic regions on flank; branchiocardiac groove deeply incised.

Long and slender appendages; P1 stout, manus of chela longer than high, granular, index may be slightly downturned; P2-P4 much more slender than P1; bases of P5 suggest it was carried dorsally. Pleon of male narrow; s 1 narrow, positioned between bases of $\mathrm{P} 5$; s 2 with lateral projections and central swelling.

Locality Type. Railroad cut exposure named Judkins Ridge near Eugene, Oregon.

Geological age. Oligocene.

Material examined. Holotype (USNM 352912 - lcxp: $42.6 \mathrm{~mm}$; wcxp: $38.4 \mathrm{~mm}$ ) and two additional specimens (hypotypes) from the same locality as the holotype (USNM $634400-$ lcxp: $~ 30$ mm; wcxp: 22.8 mm; USNM 634401 - lcxp: 36 mm; wcxp: $33 \mathrm{~mm}$ ).

Discussion. The systematic placement of Palehomola gorrelli has always been troublesome. Rathbun (1926) described the linea homolica as "... partial- 

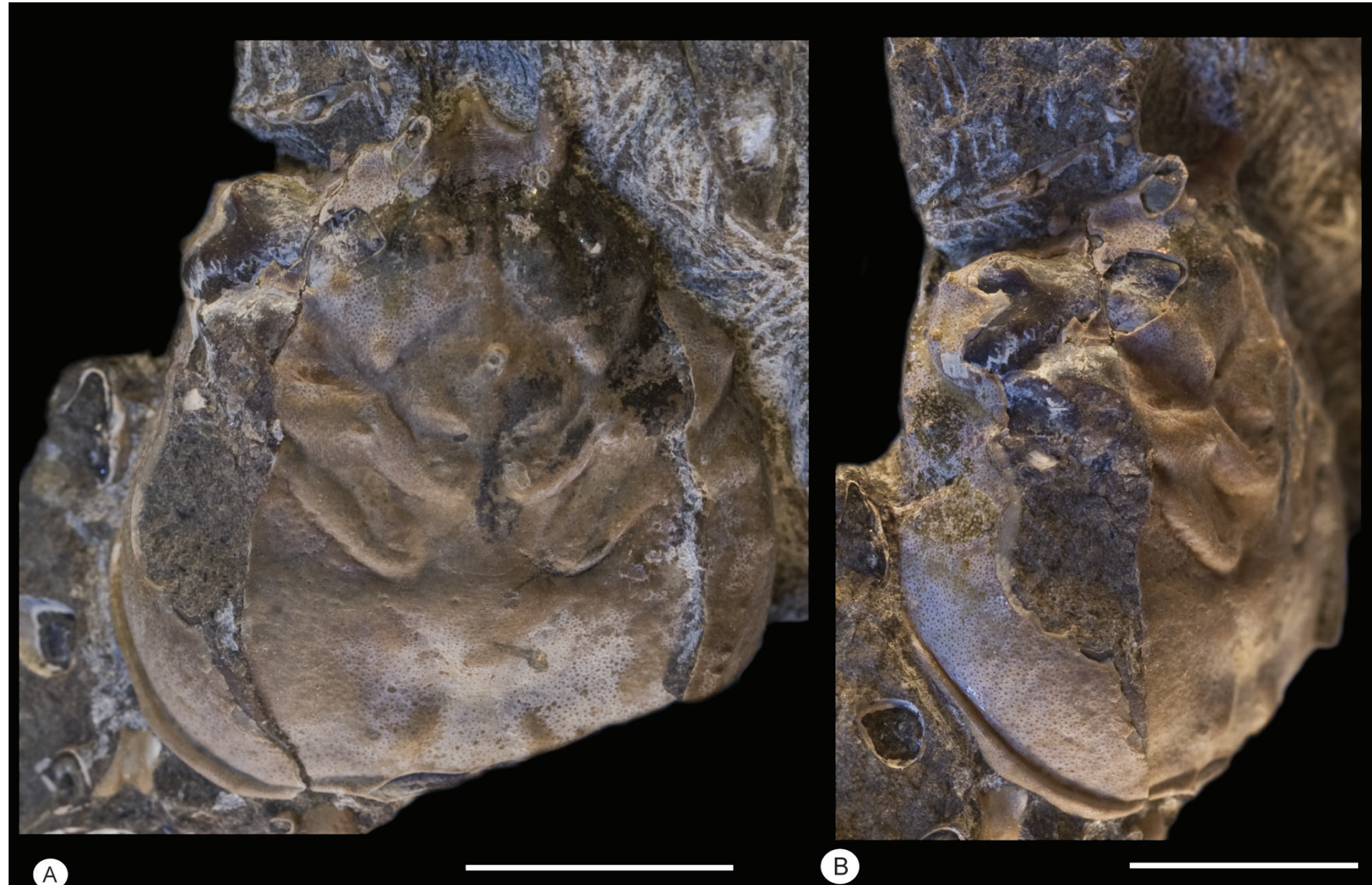

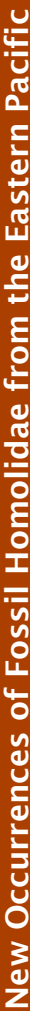

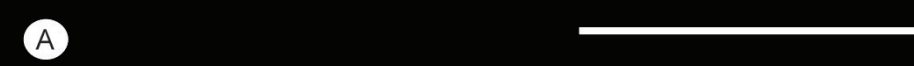

\section{B}

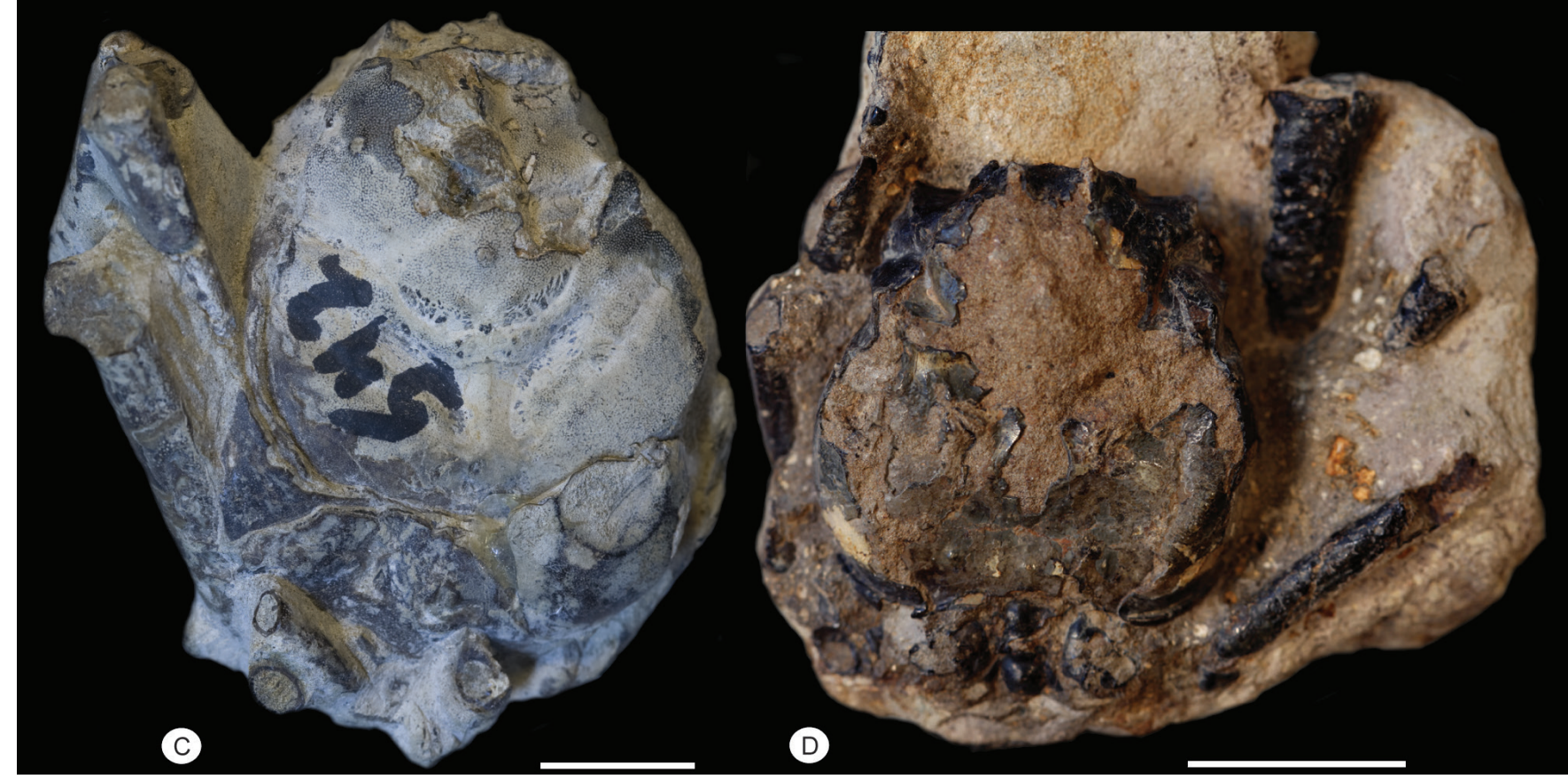

Figure 5 Palehomola gorrelli Rathbun, 1926. A) dorsal view of the carapace, hypotype USNM 634400 B) lateral view of same specimen, hypotype USNM 634400. C) dorsal view of the carapace, hypotype USNM 634401. D) holotype, USNM 352912. Scale bar equals $1 \mathrm{~cm}$. 


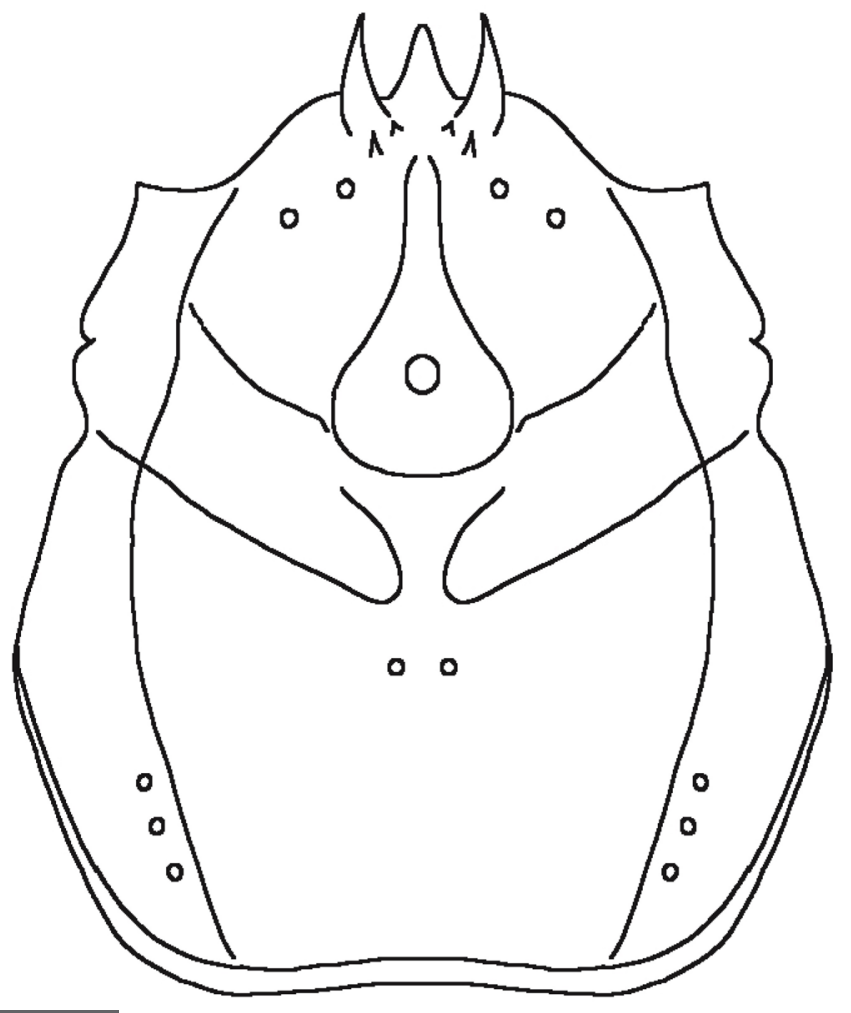

Figure 6 Palehomola gorrelli Rathbun, 1926, line drawing after holotype and hypotypes.

ly visible on left side...". Glaessner (1969) and Collins (1997) placed Palehomola within the Homolidae. Later Schweitzer (2001) suggested that Palehomola should be removed from the Homolidae based upon the lack of linea homolica. Even though Nyborg (2002) concurred with Collins (1997) in believing it to possess linea homolica Schweitzer et al. (2004) assigned Palehomola to the Homolodromiidae, a placement confirmed later by Karasawa et al. (2011). Though we confirm the apparent lack of linea homolica in the holotype, according to Schweitzer et al. (2004), the study of the additional specimen, assigned to Palehomola gorrelli and discovered from the same locality of the holotype, clearly points out the presence of this characteristic. So, according to Glaessner (1969), Collins (1997), and Nyborg (2002), we remove Palehomola from the Homolodromiidae Alcock, 1900, assigning it once again to Homolidae.

\section{Acknowledgements}

We wish to thank: Dan Bowen and Keith Sturgeon for their gracious donation of the specimens used in this study; Steve Hetrick for his expertise in fossil preparation; and the United States Museum of Natural History for loaning the specimens used for the emendation of Palehomola gorrelli. We also thank the two reviewers, Javier Luque and Gale Bishop, for their comments and suggestions in making this manuscript ready for publication.

\section{References}

Alcock, A., 1900, Materials for a carcinological fauna of India. 5. The Brachyura Primigenia or Dromiacea: Journal of the Asiatic Society of Bengal, 68(2-3), 123-169.

Alcock, A., Anderson, A.R.S., 1899, Natural History Notes from H.M. Royal Indian Marine Survey Ship "Investigator", Commander T.H. Heming, commanding. Series III. 2. An Account of the Deep-sea Crustacea dredged during the surveyingseason of 1897-98: Annales Magazine of Natural History, 7(3), 1-27, 278-292.

Allison, I.S., Felts, W.M., 1956, Reconnaissance geologic map of the Lebanon quadrangle, Oregon, 1:62500, Oregon Department of Geology and Mineral Industries Miscellaneous Geologic Map.

Baldwin, E.M., Beaulieu, J.D., Ramp, L., Gray,J.J., Newton, V.C., Mason, R.S., 1973, Geology and mineral resources of Coos County, Oregon: State of Oregon Department of Geology and Mineral Industries Bulletin, 80, $82 \mathrm{p}$.

Baldwin, E.M., 1974, Eocene stratigraphy of southwestern Oregon: Oregon Department of Geology and Mineral Industries Bulletin, 83, 40p. 
Bell, T., 1863, Some account of the Crustacea of the coasts of South America, with descriptions of new genera and species, founded principally on the collections obtained by Mr. Cuming and Mr. Miller. (Tribus 1, Oxyrhynchi): Proceedings of the Zoological Society of London, 3 (1865), 169-173.

Beurlen, K., 1928, Die fossilen Dromiaceen und ihre Stammesgeschichte: Paläontologische Zeitschrift, 10, 144-183.

Bishop, G.A., 1983, Two species of crabs, Notopocorystes (Eucorystes) eichhorni and Zygastrocarcinus griesi (Decapoda: Brachyura) from the Bearpaw Shale (Campanian) of northcentral Montana: Journal of Paleontology, 57 (5), 900-910.

Bishop, G.A., 1988, New fossil crabs, Plagiophthalmus izetti, Lathetiocarcinus shapiroi, and Sagittiformosus carabus (Crustacea, Decapoda) from the Western Interior Cretaceous, USA: Proceedings of the Biological Society of Washington, 101, 375-381.

Collins, J.S.H., 1997, Fossil Homolidae (Crustacea; Decapoda): Bulletin of the Mizunami Fossil Museum, 24, 51-71.

Collins, J.S.H., Saward, J., 2006, Three new genera and species of crabs from the Lower Eocene of London Clay of Essex, England: Bulletin of the Mizunami Fossil Museum, 33, 67-76.

Collins, J.S.H., Schulz, B.P., Jakobsen, S.L., 2005, First record of brachyuran decapods (Crustacea, Decapoda) from Fur Formation (early Eocene) of Mors and Fur Island, Denmark: Bulletin of the Mizunami Fossil Museum, 32, 17-22.

Crawford, R.S., 2008, A new species of fossil homolid crab (Decapoda: Brachyura) from the Río Foyel Formation (Paleogene), Río Negro Province, Argentina: Journal of Paleontology, 82(4), 835-841.
De Angeli, A., Alberti, R., 2012, Nogarhomola aurorae n. gen., n. sp. (Decapoda, Brachyura, Homolidae) dell'Eocene medio dei Monti Lessini orientali (Vicenza, Italia settentrionale): Studi Trentini di Scienze Naturali, 92, 63-70.

Feldmann, R.M., Schweitzer, C.E., 2009, Revision of Jurassic Homoloidea De Haan, 1839, from the Ernstbrunn and Štramberk limestones, Austria and the Czech Republic: Annalen des Naturhistorischen Museums in Wien, (A) 111, 183-206.

Feldmann, R.M., Schweitzer, C.E., Green, R.M., 2008, Unusual Albian (Early Cretaceous) Brachyura (Homoloidea: Componocancroidea new superfamily) from Montana and Wyoming, USA: Journal of Crustacean Biology, 28(3), 502-509.

Garassino, A., Clements, D., Vega, FJ., 2015, A new homolid crab, Peedeehomola deanbogani n. gen., n. sp., from the Peedee Formation (late Maastrichtian), Rocky Point Member, North Carolina, USA: Paleontología Mexicana, 4 (2), 25-29.

Glaessner, M.F., 1969, Decapoda, Arthropoda in Moore, R.C. (ed.), Treatise on Invertebrate Paleontology, Pt. R: Geological Society of America and University of Kansas Press, Lawrence, R400-R533, R626-628.

Guinot, D., 1991, Établissement de la famille des Poupiniidae pour Poupina hirsuta gen. nov., sp. nov. de Polynésie (Crustacea Decapoda Brachyura Homoloidea): Bulletin du Muséum National d'Histoire Naturelle, 4,(12) [1990], 577-605.

Guinot, D., Richer de Forges, B., 1995, Crustacea Decapoda Brachyura: Révision de la famille des Homolidae de Haan, 1839, in Crosnier A. (ed.), Résultats des campagnes MUSORSTOM 13: Mémoires du Muséum national d'Histoire naturelle, Zoologie, 163, 283-517. 
Haan, W. De, 1833-1849, Crustacea, in de Siebold, P.F. (ed.), Fauna Japonica sive Descriptio Animalium, quae in Itinere per Japoniam, Jussu et Auspiciis Superiorum, qui Summum in India Batava Imperium tenent, suscepto, Annis 1823-1830 collegit, Notis, Observationibus et Adumbrationibus illustravit, XVII, XXXI, J. Muller, Amsterdam, 109-164.

Haggart, J.W., 1991, A new assessment of the age of the basal Nanaimo Group, Gulf Islands, British Columbia. Current Research, Part E: Geological Survey of Canada, Paper 91-1E, 77-82.

Hickman, C.J.S., 1969, The Oligocene marine molluscan fauna of the Eugene Formation in Oregon: University of Oregon Museum of Natural History Bulletin, 16, 112 p.

Karasawa, H., 1992, Fossil decapod crustaceans from the Manda Group (Middle Eocene), Kyushu,Japan: Transactions and Proceedings of the Palaeontological Society of Japan, (new series) 167, 1247-1258.

Karasawa, H., Schweitzer, C.E., Feldmann, R.M., 2011, Phylogenetic analysis and revised classification of podotrematous Brachyura (Decapoda) including extinct and extant species: Journal of Crustacean Biology, 31(3), 523-565.

Linnaeus, G., Von, 1758, Systema Naturae per Regna tria Naturae, secundum classes, ordines, genera, species, cum characteribus, differentiis, synonymis, locis (ed. 10), 1, 1-824, (Laurentii Salvii, Holmiae [=Stockholm]).

McClaughry, J.D., Wiley, T.J., Ferns, M.L., Madin, I.P., 2010, Digital geologic map of the southern Willamette Valley, Benton, Lane, Linn, Marion, and Polk Counties, Oregon: Oregon Department of Geology and Mineral Industries Open-File Report O-10-03.

McKeel, D.R., 1984, Biostratigraphy of exploratory wells, northern Willamette basin, Oregon: Oregon Department of
Geology and Mineral Industries Oil and Gas Investigation, 12, 19.

Mustard, P.S., 1994, the Upper Cretaceous Nanaimo Group, Georgia Basin, in Geology and Geological Hazards of the Vancouver Region, Southwestern British Columbia: Geological Survey of Canada Bulletin, 481, 27-95.

Ng, P.K.L., 1998, Lamoha, a Replacement Name for Hypsophrys Wood Mason \& Alcock, 1891 (Brachyura, Homolidae), a Junior Homonym of Hypsophrys Agassiz, 1859 (Pisces, Teleostei, Cichlidae): Crustaceana, 71, 121-125.

Nyborg, T.G., 2002, Fossil decapod crustaceans from the early to middle Miocene Astoria Formation, Washington and Oregon, USA: Kent, Ohio, Unpublished M.S. thesis, Kent State University, 224 p.

Parisi, B., 1915, I Decapodi giapponesi del Museo di Milano. II. Dromiacea: Atti della Società italiana di Scienze naturali e del Museo civico di Storia naturale in Milano, 54, 102-116.

Porter, C.E., 1908, Nueva especie de la Fam. Homolidae. Materiales para la fauna carcinologica de Chile, VI: Revista Chilena de Historia Natural, 12(1-2), 86-88.

Prothero, D.R., 2009, Paleomagnetism and tectonic rotation of the lower-middle Eocene Umpqua Group, southwestern Oregon: Museum of Northern Arizona, 65, 83-106.

Rathbun, M.J., 1926, The fossil stalk-eyed Crustacea of the Pacific Slope of North America: United States National Museum Bulletin, 138, 155.

Retallack, G.J., Orr, W.N., Prothero, D.R., Duncan, R.A., Kester, P.R., Ambers, C.P., 2004, Eocene-Oligocene extinction and paleoclimatic change near Eugene, Oregon: Geological Society of America Bulletin, 116, 817-839.

Risso, A., 1815, Histoire naturelle des Crustacés des environs de Nice: Paris, A la Librairie grecque-latine-allemande, $175 \mathrm{p}$. 
Sakai, T., 1961, New species of Japanese crabs from the collection of His Majesty The Emperor of Japan: Crustaceana, 3(2), 131-150.

Sakai, T., 1979, Descriptions of three new species of crabs of the family Homolidae from Japan: Research on Crustacea, 9, 1-11.

Schweitzer, C.E., 2001, Additions to the Tertiary decapod fauna of the Pacific Northwest of North America: Journal of Crustacean Biology, 21, 521-537.

Schweitzer, G.E., Feldmann, R.M., 2001, New Cretaceous and Tertiary decapod crustaceans from western North America: Bulletin of the Mizunami Fossil Museum, 28, 173-210.

Schweitzer, C., Feldmann, R.M., Fam, J., Hessin, W., Hetrick, S., Nyborg, T., Ross, R., 2003, Cretaceous and Eocene decapod crustaceans from the southern Vancouver Island, British Columbia, Canada: NRG Research Press, Ottawa, Ontario, 66 p.

Schweitzer, G.E., Nyborg, T.G., Feldmann, R.M., Ross R.L.M., 2004, Homolidae De Haan, 1839 and Homolodromiidae Alcock, 1900 (Crustacea: Decapoda: Brachyura) from the Pacific Northwest of North America and a reassessment of their fossil records: Journal of Paleontology, 78(1), 133-149.
Steere, M.L., 1958, Fossil localities of the Eugene area, Oregon: The Ore Bin, 20, 51-59.

Stimpson, W., 1858, Crustacea Anomura. Pars VII. Prodromus descriptionis animalium evertebratorum, quae in Expeditione ad Oceanum Pacificum Septentrionalem, a Republica Federata missa, Cadwaladaro Ringgold et Johanne Rodgers Ducibus, observavit et descripsit W. Stimpson, Pars VII: Proceedings of the Academy of Natural Sciences of Philadelphia, 10, 225-252.

Walker, G.W., MacLeod, N.S., 1991, Geologic Map of Oregon, 1:500000, US Geological Survey.

Whiteaves, J.F., 1895, On some fossils from the Nanaimo group of Vancouver Cretaceous: Transactions of the Royal Society of Canada, (2) 1 (section 4), 119-133.

Wood-Mason, J., Alcock, A., 1891, A note on the result of the last season's deep-sea dredging: natural history notes from H.M. Indian Marine Survey Steamer "Investigator", Commander, R.F. Hoskyn, R.N. Commanding, no. 21: Annals and Magazine of Natural History, 6(7), 258-272. 